FTAMP 19.45.09

\author{
Мажитова Л.К. ${ }^{1}$, Нурланова Н.Н. ${ }^{2}$, Гилажева Э.И.. \\ Х. Досмұхамедов атындағы Атырау мемлекеттік университетінің \\ 1,2,3аға ғылыми қызметкері, Қазақстан, Атырау қ., \\ e-mail: lazzat-064@mail.ru,k.n.n.a.a@mail.ru, ilmira8381@mail.ru \\ ҚАЗІРГІ ЗАМАНҒЫ БАҚ-ТАҒЫ \\ ҚАЗАҚ АИЗАЙНЫНЫҢ МАҒЫНААЫҚ (КОГНИТИВТі) \\ ЖӘНЕ ЭСТЕТИКААЫҚ АСПЕКТІАЕРІ
}

\begin{abstract}
Қазақстан он жылда тоталитарлық жүйенің сеңін бұзып, әлемдік өркениет көшіне ілесуге, ашық демократиялық саясат жүргізуге бет а^ды және бұл бағытта үлкен жетістіктерге қол жеткізді. Қоғаммен бірге бұқаралық ақпарат құралдары да түбегейлі өзгерді. Ең бастысы, Қазақстанда өркениет талаптарына жауап беретін заңды-құқықтық база жасалды. Әлемдік журналистика мен Қазақстан бұқаралық ақпарат құралдары бір вектордағы құбылыс, оны бөле қарау немесе басқа да өлшемдердің болуы мүмкін емесі анық. Қазақ журналистикасының эволюциясы осы бағытта қалыптасып келеді, қазіргі заманғы бұқаралық ақпарат құралдарының қазақ, дизайнының когнитивті және эстетикалық аспектілерін ашуда қолданылатын көптеген әдістер мен тәсілдердің бар болуы, оның қазіргі заманға сай қолданылуында. Оған бүгінгі ғылыми-техникалық, прогресс қарқыны да қосымша демеу беріп, қамшылай түсуде. Сонымен бірге, БАҚ, дамуына ашық, нарық саясаты, іс-әрекет бостандығының берілуі де оңды әсер етті. Журналистердің психологиясы түбегейлі өзгерді, жаңа еңбек қатынастарының алғышарты түзілді, жаңа ақпараттық құра^дары пайда болды, инновациялық, жаңалықтар мен жекеменшіктік орта қалыптасты. Қазақстан журналистикасындағы өтпелі кезеңі артта қалумен жаңа жетістіктерге күннен күнге жетіп жатқанымызға көз жеткізуімізге болады.
\end{abstract}

Түйін сөздер: кингвомәдениет, журналистика, әлемдік факторлар, бұқаралық ақпарат құралдары, ақпараттық, технологиялар.

\author{
Mazhitova L.K. ${ }^{1}$, Nurlanova N.N. ${ }^{2}$, Gilazheva E.I. ${ }^{3}$, \\ $1,2,3$ senior lecturer of $\mathrm{H}$. Dosmukhamedov \\ Atyrau State University, Kazakhstan, Atyrau, \\ e-mail: lazzat-064@mail.ru, k.n.n.a.a@mail.ru, ilmira8381@mail.ru.
}

\title{
Art directions of the development \\ of Kazakh literature in the XIX century
}

For decades, Kazakhstan has broken the totalitarian system, pursued global civilization, pursued an open democratic policy and achieved great success in this direction. Together with the society, the media has radically changed. Most importantly, Kazakhstan has created a legal framework that meets the requirements of civilization. Global journalism and Kazakhstani media can be a vector phenomenon; it cannot be divided according to other criteria. The evolution of Kazakh journalism is developing in this direction, and its obvious fruits are too great. The pace of modern scientific and technological progress is also encouraging to improve quality. At the same time, the development of open media, market policy and freedom of action also had a positive impact. The psychology of journalism has radically changed, new prerequisites for labor relations have been created, a private environment has been formed. It can be concluded that the transition period in journalism in Kazakhstan is far behind.

Key words: linguistic culture, journalism, global factors, media, information technology. 


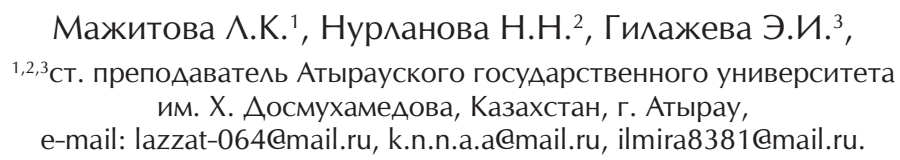

Когнитивно-эстетические аспекты казахского дизайна в современных средствах массовой информации

\begin{abstract}
На протяжении десятилетий Казахстан вышел из тоталитарной системы, преследова^ глобальную цивилизацию, проводил открытую демократическую политику и Аостиг больших успехов в этом направлении. Вместе с обществом радикально изменились и СМИ. Самое главное, что в Казахстане создана правовая база, отвечающая требованиям цивилизации. Очевидно, что мировая журналистика и средства массовой информации Казахстана не могут быть явлениями в одном векторе, его разделением или другими критериями. Эволюция казахстанской журналистики развивается в этом направлении, доступности многих методов и приемов, используемых при раскрытии познавательных и эстетических аспектов казахстанских СМИ в современных средствах массовой информации, в их современном применении. В то же время, развитие открытых СМИ, рыночная политика и свобода действий также оказали положительное влияние. Психология журналистики радикально изменилась, появились новые предпосылки Аля трудовых отношений, появились новые информационные инструменты, новаторские новости и частная среда. Мы можем быть уверены, что с переходным периодом в журналистике в Казахстане мы сегодня Аостигаем новых высот.
\end{abstract}

Ключевые слова: ^ингвокультура, журналистика, глобальные факторы, среАства массовой информации, информационные технологии.

\section{Кіріспе}

Бүгінгітаңдағыәлеуметтікмәденитанымжәне ұлттық мәденитаным мен таңбалар жиынтығын зерттеу лингвомәдениеттаным, этнолингвистика айналысатын нысандардың өзегі болып табылады. «Лингвомәдениеттанудың ең негізгі әрі басты категориясы - әлем бейнесі ұғымы. Жекелеген адам үшін, кеңінен қарастырғанда, этнос үшін өте маңызды ұғымдар мен концептілерді тану - ғылым саласы ретіндегі мәдениттанудың басты мақсатын айқындайды. Бұл қаншалықты анықтала түскен сайын, қолданыстардың ұлттық-танымдық концептуалдануының әлемдік тілдік бейнесімен байланыста болуының себебі де соншалықты түсінікті бола түседі. Ұғым мен концептілерді танып білудің негізінде олардың қандай тілдік таңбалармен таңбаланатынына назар аудару жатады», - дейді ғалым Б. Момынова (Momynova B., 2008: 256). «Тілдік таңбалардан көрініс беретін мәдени дүниетаным ұрпақтанұрпаққа ұласып, этностың өзін қоршаған дүниені мәдениет тұрғысынан тану процесінде қалыптасқан жаңа қоғамның санасына жетуі тиіс» (Telı1a V.N., 1997: 217) екенін ескерсек, бұл құбылыс тіл мен мәдениетті сабақтастықта зерттеуге негіз болады. Тіл мен мәдениет сабақтастығы адамдар ұжымының әлеуметтік әлеуетіне (потенциал) сай халықтың тілдік санасымен, ментальдық ерекшелігімен тікелей байланысты. Мәдениетті таңбалаушы тілдік бірліктер халықтың танымын, рухын, дінін, ділін, ұлттық психологиялық ерекшелігін танытады. Мұндай ерекшеліктер бұқаралық апарат құралдарының беттерінде кездеседі. Олар тіл мен мәдениет арасындағы философия, социология сияқты ғылымдардың тоғысын таныта келіп, лингвомәдениеттанымдық көрсеткішке айналды.

Әлем халықтары мәдениеттерінің ежелгі замандардағы шығармашылық мұраларынан бастап қалыптасқан рухани меншіктілік категориясы. Авторлық қазіргі уақытта рухани мәдениет, қоғамдық-әлеуметтік орта, құқықтық қарым-қатынастар аясында ғылымдық мәні бар кең үғымдағы сөз. «Автордың бейнесі»,»авторлық колжазба», «авторлық қолтаңба», «авторлық таблицалар», «авторлық келісімшарт»,»авторлық құқық»,»авторлық куәлік» және т.б. мемлекеттік-ресми атаулар бұл ұғымның қолданыс аясының кеңдігін көрсетеді. Қоғамдағы материалдық және рухани мәдениет салаларындағы сан алуан шығармашылық қызметтерге байланысты қолданылатын авторлық категорияның маңыздылығы күн өткен сайын арта түсуде.

Көркемөнер туындыларын жасаудағы шығармашылық туындыгерлік тұлғасы өзі дүниеге келтірген шығармасы аркылы танылады. Жеке адамға тән сезім толғаныстары иірімдері, өзінің өмір тәжірибелері мен қоршаған ортаға арналған дүниетаным көзқарастары шығарманың өмірта- 
нытқыш мазмұнын жасайды. Әдебиет-мәдениет мазмұнды иеленген өнер туындысындағы автор тұлғасының танылуы мағынасында туындыгер мен оны қоршаған адамдар ортасы арасындағы объективті-субъективті психологиялык карымкатынастар бар. Автор тұлғасы көркемәдебиеттің негізгі табиғатын танытатын эстетикалық танымдык ерекшелік. Қазақ сөз өнерінің тарихын әдеби процесс категориясының аясында түсіну үшін әдеби шығармалардағы автордың өзіндік тұлғасының даралана танылу кұбылысына назар аударылады.

Адамдар өзін қоршаған ортадағы заттар мен құбылыстарға баға берсе, бағалау тек заттар емес, адам өзі танып білген кез-келген нәрсенің жақсы-жаманын, пайдасын, зиянын ажырата білуінен де көрініс табады. Бағалау адамдардың ойлану процесінен пайда болады. Ойлану түрлі тәсіл, амал операциялардан тұрады. Олар: анализ (талдау), синтез (жинақтау) жалпылау, нақтылау, абстракциялау, жүйелеу т.б. (Jaryqbaev Q. Tabyldıev Á., 1994: 144).

Бағалауыштық құрылым бағаланып отырған заттың адам өміріндегі маңыздылығымен өлшенеді. Егер заттың бағасы жалпы халықтың күнделікті тыныс-тіршілігіне сай өлшенсе, ол затқа берілген атаулар тілде ақпарат құралы ретінде жұмсалады. Егер затың бағасы халықтың тыныс тіршілігімен байланысты болып, белгілі бір ұлттың мәдени өміріне қатысты таптауырындар (стереотип) түрінде берілсе, ол затқа берілген атаулар әр халықтың ғасырлар бойы қалыптасқан салт-дәстүр, әдет-ғұрыпы мен әдебін танытатын тілдік құрал ретінде жұмсалады. Бағалауыштық құрылымды ғалым Б.Момынова субъект баға/ негіх объект түрінде көрсетіп, бағаның салыстырмалы баға, абсолютті баға, жалпы және дара баға деп аталатын үш түрін көрсете келіп «салыстырмалы баға бергенде «жақсы», «жаман», «тепе тең», ал абсолюттік бағалауда «жаман» және «жақсы», «бәрібір» ұғымдарын пайдаланамыз. Ал жалпылама баға берерде заттың барлық қасиеттері жинақталып, есепке алынса, жеке дара заттың бір ғана аспектісінің негізінде, бір ғана ерекшелігі арқылы беріледі. Абсолюттік бағалау кезінде бағаланатын объект біреу ғана болса, салыстырмалы баға берілерде екі немесе бірнеше объект бағалауға қатыстырылады, болмаса бір объектінің екі түрлі хал-күйі, жағдайы салыстырылады» деп тұжырымдайды (Momynova B., 2005: 140).

«Бағалауыштық құрылым адамның өмір тәжірибесінен алған көңіл күймен байланыста отырып, сол арқылы сөздің семантика- сына, мағына мәселесіне, эмоционалдық категориясына, адамның ішкі лексиконына баға береді және оның әлеуметтік нормасын анықтайды» (Zalevska1a A.A., 1997: 83) деген А.А.Залевскаяның тұжырымы тіліміздегі сөздердің функционалдық қызметін анықтаудың бірден бір жолы ретінде танылады. Қ.Жұбанов: «Бір сөздің өзінде екі функция болады. Біріншісі - хабар беру қызметі, немесе коммуникациялық функция; екіншісі - таңбалау қызметі, яки сигнификация» - дейді (Jubanov Q., 1999: 581). Сөздің хабар беру қызметін екі типке бөлуге болады. Бірінші тіл мен ой бірлігін айқындайтын тип. Бұл тип бойынша, сөз белгілі бір заттың атауы ретінде дербес тұрса да, ол тілді тұтынатын әрбір адамның санасында өмір сүреді, таным процесінде шешуші рөл атқарады, тіл мен ойлаудың бірлігін құрайды. Бұл жөнінде Қ.Жұбанов былай дейді: «Ой деген адамның өзі жайлы, болмаса төңіректегілер жайлы білгені. Сөз деген сол білген нәрселердің аты. Сондықтан адамдар заттармен құбылыстардың аттарын (сөздерді) айтып білдіреді, яғни ойын сөзбен білдіреді» (Jubanov Q., 1999: 581). Ғалымның бұл тұжырымы - сөз бен ойдың бірлігін айқындайтын лингвофилософиялық концепция. Сөз бен ой - ажырамас диалектикалық бірлік. Бұл сөйлеу мен ой бірлігін құрайды.

\section{Эксперимент}

Сөздің танымдық қызметі екі түрлі: бірінші, шындық болмыстағы заттар мен құбылыстардың атауын көрсетеді; екінші, шындық болмыстағы заттар мен құбылыстар туралы хабар береді. Мұны сөздің функционалдық қызметі тұрғысынан былайша түсіндіруге болады: сөзді айтқан кезде адам миына ең әуелі, ол қандай құбылыстың атауы екені туралы сигнал келеді. (Заттық атау ма, сындық атау ма, қимылдық атау ма, мезгіл атауы ма, мөлшер атауы ма) Одан кейін оның мағынасы туралы хабар келеді. (Қандай зат, қандай қимыл, қандай мезгіл, қандай мөлшер т.б.) Бұл екі қызмет сөз бен мағынаның ішкі бірлігін құрайды. Нәтижесінде олар тіл мен ойлаудың арақатынасын анықтауға негіз болады. Яғни сөз дыбыстық тілдің көрсеткіші болып танылады да, мағына ойлаудың көрсеткіші болады. Нәтижесінде сөз бен мағынаны адам болмысымен өзара үндесімде, бірлікте жұмсалатын антропологиялық фактор деп тануға болады.

Бүгінде БАҚ-та қалыптасқан жағдай ақпараттық және компьютерлік технологиялардың орасан қоғамдық күшке айналғандығын, 
қоғамдық сананы қалыптастырудағы рөлі арта түскендігін, жауапкершілігі де ұлғайғандығын көрсетеді, жұмысты ұйымдастыруда, ақпарат жинау мен таратуда жетекші мәнге ие болғандығын шегелей түседі.

Қазақстан БАҚ болашағы да әлемдік факторларға байланысты. Керісінше, ашық саясат ол арақашықтықты жақындата түсті, кедергілерді жойды. Сонымен бірге, біздің БАҚ та өркениет болашағы үшін жауапкершіліктен сырт қала алмайды. Яғни, елімізде орын алып отырған қиындықтарды тез жеңуге, экономиканы көтеруге, экологияны, басқа да әлеуметтік проблемаларды шешуге, халықтың білімі мен мәдениетін көтеруге, басқа да рухани сұраныстарын қанағаттандыруға, ғылыми техникалық жаңалықтарды өмірге еңгізуге ыңпал етіп, қоғамдық күш ретінде жауапкершілікті өзіне алғанда БАҚ-тың да беделі өсіп, танымалдығы арта түседі.

Әлемдік журналистика мен Қазақстан бұқаралық ақпарат құралдары бір вектордағы құбылыс, оны бөле қарау немесе басқа да өлшем болуы мүмкін емес. Қазақ журналистикасының эволюциясы осы бағытта қалыптасып келеді, оның нақты жемістері де көп күттірмейтіні анық. Оған бүгінгі ғылыми-техникалық прогресс қарқыны да қосымша демеу беріп, қамшылай түсуде.

Қазақстандық БАҚ-қа қатысты мына бір проблеманың да мәні зор. Ол меншік иелеріне қатысты. Мемлекеттік монополияның жойылуына байланысты, газет журналдардың, телерадиоарналардың, баспалардың қожайындары да өзгерді. Өкінішке орай, осы арада демократиялық айқындылық принципі сақталды деп айту қиын. Әңгіме сапалы басылымдар туралы болып тур. Бұрыннан халыққа кең танымал БАҚ-тардың жаңа заңды формаларға көшкенімен, кім, қалай басқаратындығы, қаржы көздері, жарнама бюджеті туралы мағлұматтар жоқ. Жабық акционерлік қоғамдар мен әр түрлі бірлестіктердің аты қарапайым оқырман, көрермен тыңдарманға еш мағлұмат бермейді. Мұның өзі олар тарататын ақпараттың оқырман үшін сенімділігіне тікелей әсер ететін фактор екендігін де ұмытуға болмайды. Біздің масс-медианың қандай топтарға, болмаса күштерге сүйенетіндігін, ақпарат көздерін қайдан алатындығы мен техникалық және технологиялық мүмкіндігін білуіміз өркениет талаптарына сай факторлар болып келеді.

Бұқаралық ақпарат құралдарында компьютерлік бағдарламалар саласында Қазақстанда қалыптасқан мынандай проблемаларға назар аударуымыз керек.

Бірінші, қазақ тіліндегі бағдарламалардың нарықта өз жолын таба алмауы, сұраныстың жоқтығы, сондықтан жетілдірілмей қалып қоятындығы.

Екінші, қазақ әріптері ұяларындағы сәйкессіздік тауқіметі. Шетелдік мамандарға компьютерде қазақ әріптерімен терім жасаудың оннан аса стандарты қалыптасқандығын түсіндіре алмайсыз. Өйткені, олар үшін бұл тым ақылға симайтын ұғым. Компьютермен әмбебап құрал болғандықтан бұра тартудың қаншалықты қажеті барлығын өздері де түсіне алмай келеді. Компьютер өмірімізге алғаш араласа бастаған кезде, қазақша теру қажеттігі туындап, әріптер жасауға сұраныс күшейді. Осыны пайдаланған әр фирма өкілдері көрпені өзіне қарай тартуға ұмтылып, өз стандартын қалыптастыруға тырысты. Мүмкін, ол бүкілқазақстандық стандартқа айналса, сатып табысқа кенелеміз деген де ойдың болуы мүмкін. Осының салдарынан енді әріпке сұраныс емес, артық жүк балластан құтылу тауқіметі күшейді. Сөйтіп, ақпараттық ғасыр жаңа мыңжылдыққа да қадам бастық, проблема сол күйінде қалып қойды.

Үшінші, үлкен бір мәселе қазақ тілінің латын әліпбиіне көшуінен туындайды. Ақпараттық қоғам болашағы, технологиялардың үрдіс дамы тұрғысынан қарасақ, көшудің тиімділіктері айқын көрінеді. Бұл жерде өткендігі бай мұрамыздан қара үземіз деп жалтақтаудың еш негізі жоқ. Әңгіме жаңа әліпбидің сауатты ережесін жасап, логикалық алгоритмін дұрыс құруда, әрі қазақы дыбыстардың үндестігін сақтауда. Мүндай жағдайда қазіргі кезеңнің компьютерлік қуатымен оны тиімді жүзеге асыру көп шығынды да қажет етпейді. Мысалы, білікті компьютерлік бағдарлама жасаушыға оның алгоритмімен сүзгі (фильтр, кейде конвертор деп те атайды) жасау ет пісірім уақытын ғана алады. Оны, мысалы, кең тараған Word бағдарламасына енгізіп, іске қоссаңыз, бір ноқатын басумен мәтініңізді ескі кириллицаға, кері бассаңыз жаңа латыншаға ауыстырып беру мүмкіндігін қарастыруға болады, компьютерлік тәжірибеде бар нәрселер. Яғни, жүздеген оқулықтарыңызды компьютер бірер сағатта жаңа әліпбимен түзіп шығады.

Бұл мәселеде де Мәдениет, ақпарат және қоғамдық келісім министрлігінің құзырлы өкілеттігі мен белсенді араласуы керек деп ойлаймын. Бірінші кезеңде ғалымдар, педагогтар, қоғам қайраткерлері, зиялы қауым ортасында 
кең ауқымды сұрау салуға сол арқылы қоғамдық пікірді зерттеуге болар еді. Келесі ретте, тіл және компьютер мамандарының басын қосып, нақты ұсыныс, варианттар әзірлеу, оны алқалы ғылыми конференцияда талқылау эөн тәрізді. Дүниежүзі қазақтарының екінші құрылтайына дейін осы мәселе пісіп жетілсе, бір тоқтамға келсе нұр үстіне нұр болып, компьютерлік технологияларды еркін пайдалануымызға кең жол ашар еді. Осы форумға тиянақты ой тұжырымдалып, мемлекеттік шешімді қабылдауға ұсыныс жасалca, өркениетті үрдістегі оң қадамымыз болып, халықтың да көкейінен шығатыны анық.

Төртінші, компьютерлік бағдарламаларды қолдануда авторлық құқық нормаларының сақталмайтындығы. Мамандардың пікірінше, Қазақстанда қолданылып жүрген бағдарламалардың тоқсан пайыздан астамының лицензиясы заңдастырылмаған. Яғни, бұл бағдарламалар қарақшылық лазерлік дискілердің көшірмесі болып табылады, авторлық құқық нормалары сақталып, оларға тиісті ақысы төленбеген. Бұл экономикамызға кері әсер ететін маңызды факторлардың бірі болып отыр. Өйткені, компьютерлік бағдарламаларды жаппай заңсыз пайдалану әлемдік интеграцияға кедергі келтіріп, жетекші компьютерлік фирмалар Қазақстан нарығында жұмыс істеуге құлшыныс білдірмеуде, сауда саттық мәселелерінде сенімсіздік туғызуда. Оның үстіне ол ұлттық ақпараттық қауіпсіздігімізге де кесірін тигізеді. Өйткені, заңсыз алынған бағдарламалардың қалыпты жұмыс істеуіне ешкім кепілдік бере алмайды, олармен бірге вирустар тарауы, компьютерлік мағлұматтар жойылып кетуі де мүмкін. Мұның бірден бір жолы редакциялардың компьютерлік бағдарламаларды орнатуда арнайы рұқсаты бар фирмалармен жұмыс істеп, заңды құқықтарды сақтауына міндеттеу болыр табылады. Ондай заң талаптары республикамызда қабылданған, тек соның қолданыс табуы орынсыз кешігуде, өкілетті орындар оған мән бермей келеді.

Бесінші, мемлекеттік тілдің қолдану аясын кеңітуде жоғарыдағыдай кедергілер жойылғанда ғана, адамдардың бойынша сенімділік пен наным қалыптасады. Сонда ғана қабылданған шараларды жүзеге асыруға кең жол ашылады, адамдардың психологиясындағы өзгеріс қана қазақ тілін оқып-үйренуге, сөздік қорын байытуға ұмтылдырады.

Алтыншыдан, белгілі бір стандарт қалыптасқанда ғана бухгалтерлік есеп, статистика, банк операциялары тәрізді күрделі мемлекеттік маңызды шаралар қазақ тіліне бейімделетін болады.

\section{Нәтиже мен талқы}

Өзінің «Ұлттық идея және идеология» деп аталатын еңбегінде академик Д. Кішібеков оны былайша тарқатып айтады: «Мемлекеттік ұлт деп, егер ол тұтас мемлекетті қамтыған жағдайда (ұлттық біртұтас мемлекет) немесе ұлттық гомогендіктің (біртектіліктің) тасымалдаушысы болған жағдайда аталады. Алайда бұл ұғымның астарынан, сондай-ақ бірнеше ұлттарды қамтитын кейбір мемлекетте (мультимәдени) қалыптаса алатын біртұтас сананы білдіретін жетекшілік рөлді аңғаруға да болады. Ал егер ұлттық әралуандылықты құрайтын бір ұлттың жағдайына келсек, онда ол субұлтты білдіреді. Ақырында, мәдени ұлт дегеніміздің мемлекетке бірегейленуге қатысы жоқ ұлтты айтады. Бұл ұлт біртұтас ұлттық мемлекет құруға қабілетсіз немесе бірнеше мемлекеттерге бөлінген болуы да мүмкін» (Kishıbekov D.K., 2005).

Қазақстанның тәуелсіздігінің нығаюы барысында елімізді мекендейтін әртүрлі ұлт пен дін өкілдерін бір қоғамға біріктіріп, ұйыстыратындай ұлттық идеяны қалыптастыруда Елбасы Нұрсұлтан Назарбаевтың зор еңбегі бар екенін атап өту керек. Президент ұлттық идеяны қазақ халқының қоғамды топтастырудағы жұмылдырушы (консолидацияландырушы) рөлімен байланыстырады. Мұны Президент Нұрсұлтан Назарбаевтың Қазақстан халқы Ассамблеясының сессияларында сөйлеген сөздерінен аңғаруға болады. Мысалы, Қазақстан халқы ассамблеясының 1995 жылғы 24 наурыздағы бірінші сесиясындағы оның баяндамасы «Біздің ортақ үйіміздегі бейбітшілік пен келісім үшін» деп аталды және онда былай делінді: «Уақыттың ауыр сынынан өткен қазақ халқының бай да күрделі тарихы бар. Бүгінгі күні ол Қазақстанда тұратын барлық халықтарға көмек беруі тиіс, біздің бірлігіміздің түбірлерін дұрыс түсініп, кез келген тарихи түртпектеуді теріске шығаруы қажет, өйткені артқа көз сала отырып, келешекті көруіміз керек» (Nazarbaev N., 2009: 7).

Өтпелі кезеңде және одан кейінгі даму барысында, әсіресе XXI ғасырдың табалдырығында Қазақстанда бірнеше үлгілер ұсынылды және ұлттық идея төңірегінде академик Ә. Нысанбаев бастаған қызу пікірталастар баспасөз бетінде жарияланды (Nurmuratov S.E., 2005). «Ұлттық идея: талқылауға ұсыныстар» деп аталатын академик 
бастаған бір топ ғалымның пікірлері баспасөз беттерімен қатар, мерзімдік арнаулы ғылыми басылымдарда да жалғасын тапты. Бұл тақырыпқа қатысты Философия және саясаттану институты бірнеше көлемді монографиялар жариялағанын да жоғарыда атап өттік (Obshenatsionalna1a 1de1a Kazahstana, 2006).

Ұлттық характер - әдеби шығармадағы кейіпкердің ұлттық сипатымен ерекшеленеген мінез-бітімі, оның белгілі бір халықтың өкілі екендігін танытатын психологиялық және ойлау, сөйлеу өзгешелігі. Ұлттық характер - тарихи категория. Ол қоғамдық, рухани, экономикалық және саяси жағдайларға сәйкес қалыптасады. Дүниені ұлттық түсінікпен қабылдау жолы қай адамға болсын тән қасиет. Өнерде де, әдебиетте де адам бейнесінен бұл қасиет толық көрініп отырады. Әр халықтың өз эпикалық туындыларын олардың талай замандар ұлт болып қалыптасуынан бөліп қарауға болмайды. Сондықтан шығармада ұлттық характер жасау үшін, оның дүниетанымын, психологиясын, әдет-ғұрыптарын, т.б. қасиеттерін білу керек.

2004 жылдың тамыз айында «Казахстанская правда» газетінде Мұхтар Құл-Мұхаммедтің «Ұлттық болмыстың негізі» деп аталатын көлемді ғылыми-көпшілік мақаласы жарияланды және бұл еңбекте ұлттық идея тілмен байланыстырылды. Автор мынадай түйінді ойлар айтады: «Тіл қашанда ұлттық идеяның басты құрамдасы және мемлекеттік идеологияның негізі болды. Оның үлгілерін қазіргі заманғы тарихтан көптеп келтіруге болады...

XXI ғасырдың басындағы ұлттық идеяны іздестіруді алдыңғы ғасырдың басындағы зиялы қауымның ұлттық сананы оятуға ұмтылуымен салыстыруға келеді. Мысалы, Алаш арыстарының бірі Жүсіпбек Аймауытов большевизмнің билік басына келе бастаған тұсындағы ұлт саясатының тағдыр талайын бағамдап, ұлт бостандығын көксеп, қазақ елінің келешегіне алаңдап «Ұлтты сүю» деген мақала жазса (Aımaýytov J., 1918), жас көсемсөзшіжурналист Амангелді Кеңшілікұлы «Қазақстан» газетінде «Қазақты сүю» деген мақала жазды (Keńshilikuly A., 2008).

\section{Қорытынды}

Сонымен бірге, БАҚ дамуына ашық, нарық саясаты, іс-әрекет бостандығының берілуі де оңды әсер етті. Журналистердің психологиясы түбегейлі өзгерді, жаңа еңбек қатынастарының алғышарты түзілді, жекеменшіктік орта қалыптасты. Қазақстан журналистикасындағы өтпелі кезең артта қалды деп ой тұжырымдауға болады.

БАҚ дамуының алғышарттары мен белгілері мыналар:

- жаңа БАҚ ашу тіркеумен ғана шектелді, сөз бостандығына жол ашылды;

- әлемдік ақпараттық ортаға интеграциялану күшейді;

- мемлекеттік монополия жойылды;

- жекеменшіктік қатынас және бәсекелестік орнықты;

- баспа, техника мен технологиялар, шикізат, құралдар нарығы қалыптасты;

- жаңа мамандар: менеджерлер, журналистер, баспагерлер, режиссерлер, продюсерлер, жарнама және басқа да БАҚ-қа қызмет ететін салалар мамандары қалыптасты;

- инновациялық сапалық көрсеткіштерге алып келді: ақпараттардың ұшқырлығы артты, газет-журналдардың мазмұнымен қоса полиграфиялық сапасы жақсарды, жаңаша дизайн қалыптасты, қаріптерді кең, әрі құбылта пайдалану жүзеге асты, суреттер көп қолданыла бастады, жаңа типті фотоколлаждар дүниеге келді, безендіру элементтері байытылып, көркемдеу стилі мен бағыттарының сан түрі қолданысқа енді;

- телерадиохабарларын даярлауда да жаңа технологиялар кең шығармашылық мүмкіндіктерге жол ашты;

- жұмысты ұйымдастырудың жаңа формалары мен әдіс-тәсілдері өмірге жолдама алды;

- Интернет пен электрондық почта кең қолданысқа еніп, БАҚ-тың шекарасын кеңейтуге ықпал етті, ақпараттық желілік Веб-сайттар жүниеге келді;

- жарнама саясаты түбегейлі өзгерді;

- жаңа БАҚ қожайындарына табыс әкелетін бизнес көзіне айналды.

Ақпараттық технологияларды дамыту Қазақстан Республикасының даму стратегиясында қарастырылған жетібасым бағыттардың бірі болып саналады. Оның «Инфрақұрылым» бөлімінде мына міндеттер қойылады: «Ақпараттық технологиялар, оның басқа түрлерімен салыстырғанда, өз мәнісі жағында неғұрлым «көпшіл» әрі икемді бола отырып, бизнесті, экспорттық қызметті дамытуғажәне экономиканы орталықсыздандыруға барынша жәрдемдеседі. Олар ұлттық экономиканы шоғырландырады және аймақтың ауқымын кеңейте отырып, әлемдік экономикалық байланыстарды нығайтады. 
Бүгінгі күні де қазақ халқының ұлттық идеясына қатысты өзекті мәселелер күн тәртібінен түспей отыр. Жаһандану дәуіріндегі қазақтың мұң-мұқтажына алаңдаушылық танытқан саясаттанушы Б. Әбдіғали қазақ жобасын, қазақ идеясын, қазақ ойын, қазақ сөзін, қазақ саясатын, қазақ миссиясын, қазақ даңқын қозғайтын «Қазақ» альманағын жариялауда. Аталмыш еңбектерде дәстүрлі және қазіргі дүниетанымдық бағдарлар мен құндылықтардың, мақсатмүдделер мен мұраттардың тұтастай кешенімен сипатталатын ұлттық идея қазақ халқының рухани мәдениетінің тарихынан да, бүгінгі әлеуметтік-мәдени өмірінен іздестіріледі және бұл зерттеудің әдіснамалық негізін айқындауға септігін тигізеді.

\section{Әдебиеттер}

Аймауытов Ж. Ұлтты сүю. - Абай журналы, 1918.

Жарықбаев Қ. Табылдиев Ә. Әдеп және жантану.Атамұра - Алматы,1994. - 1446.

Жұбанов Қ. Қазақ тілі жөніндегі зерттеулер. - Алматы, 1999. - 581 б

Залевская А.А. Проблемы организации внутреннего лексикона человека. - Калинин: КТУ, 1997. - 83 с.

Кеңшілікұлы А. Қазақты сүю. - Қазақстан, 2008.

Кишибеков Д.К. Национальная идея и идеология. - Известия Казахстана, 2005.

Момынова Б. Шәкәрім поэзиясының тілі. Арыс. - Алматы, 2008. - 256 б.

Момынова Б. Қазақ тіліндегі қоғамдық саяси лексика: әлеуметтік бағалауыштық сөзжасам. - Алматы, 2005. - 140 б.

Назарбаев Н. Консолидирующая роль казахов. Қазақ альманағы № 01. - Алматы, 2009. - 7 б.

Нұрмұратов С.Е. Ұлттық идея баршаның ортақ құндылығы / Адам әлемі, №4. - Алматы, 2005.

Общенациональная идея Казахстана: опыт философско-политологического анализа. КИЦ ИФиП МОН РК. - Алматы, 2006. $-412 \mathrm{c}$.

Телия В.Н. Русская фразеология. Семантический, прагматический и лингвокультурологический аспекты. Прогресс. M., 1997. -217 c.

\section{References}

Aımaýytov J. (1918). Ultty sú1ý. [Love the nation] Aba1 jýrnaly. (In Kazakh).

Jaryqbaev Q. Tabyldıev Á. (1994). Ádep jáne jantaný.Atamura. [Ethics and animosity] Almaty, 144 b. (In Kazakh).

Jubanov Q. (1999). Qazaq tili jónindegi zertteýler. [Research on the Kazakh language] Almaty, 581 b. (In Kazakh).

Zalevska1a A.A. (1997). Problemy organızats11 vnýtrennego leksıkona cheloveka. [Organization of internal lexicon problem] Kalının, 83 s. (In Russian)

Keńshilikuly A. (2008). Qazaqty sú1ý. [Love the kazakh] Qazaqstan. (In Kazakh).

Kishıbekov D.K. (2005). Natsıonalna1a 1de1a 1 1deologi1a. [National idea and ideology] Izvestı1a Kazahstana. (In Russian)

Momynova B. (2008). Shákárim poezı1asynyń tili. [Language of Shakarim Poetry] Almaty, 256 b. (In Kazakh).

Momynova B. (2005). Qazaq tilindegi qoǵamdyq saıası leksıka: áleýmettik baǵalaýyshtyq sózjasam. [Social political vocabulary in the Kazakh language: socially valued words] Almaty, 140 b. (In Kazakh).

Nazarbaev N. (2009). Konsolıdırýı́aı rol kazahov. [The consolidating role of the Kazakhs.]Qazaq almanaǵy. Almaty, 7 b. (In Russian)

Nurmuratov S.E. (2005). Ulttyq 1deı barshanyń ortaq qundylyǵy. [The national idea is a shared value] Adam əlemi, №4. Almaty. (In Kazakh).

Obshenatsionalnaia 1de1a Kazahstana (2006).Opyt filosofsko-politologicheskogo analiza. [The national idea of Kazakhstan] MON RK. Almaty, 412 s. (In Russian)

Telı1a V.N. (1997). Rýsskaıa frazeologı1a. Semantıcheskı1, pragmatıcheskı1 1 lıngvokýltýrologıcheskı1 aspekty [Russian phraseology. Semantic, pragmatic and linguocultural aspects] Moskva, 217 s. (In Russian) 